\title{
Morphology engineering of basidiomycetes for improved laccase biosynthesis
}

\author{
Anna Antecka • Michał Blatkiewicz • \\ Marcin Bizukojé · Stanisław Ledakowicz
}

Received: 26 October 2015/Accepted: 10 December 2015/Published online: 23 December 2015

(C) The Author(s) 2015. This article is published with open access at Springerlink.com

\begin{abstract}
Objective This work is the first application of a morphological engineering technique called microparticle-enhanced cultivation (MPEC) aimed at the facilitation of laccase production in the submerged cultures by two basidiomycetes species Cerrena unicolor and Pleurotus sapidus.

Results The positive effect of the applied $10 \mu \mathrm{m}$ $\mathrm{Al}_{2} \mathrm{O}_{3}$ microparticles at concentrations from 5 to $30 \mathrm{~g}$ $\mathrm{Al}_{2} \mathrm{O}_{3} 1^{-1}$ was shown. Laccase activity increased 3.5fold for C. unicolor and 2-fold for P. sapidus at $15 \mathrm{~g}$ $\mathrm{Al}_{2} \mathrm{O}_{3} 1^{-1}$ on 9 and 14 day of the cultivation, respectively, compared to the control culture without microparticles. The increase of laccase activity in the cultivation broths was caused by the action of $\mathrm{Al}_{2} \mathrm{O}_{3}$ microparticles on the agglomeration of hyphae. It led to the decrease of the size of the pellets, (on average by $2 \mathrm{~mm}$ for $C$. unicolor), the change of their shape (starshaped pellets for $C$. unicolor) and the change of their structure (more compact pellets for $P$. sapidus).

Conclusions Application of MPEC for the submerged cultures of two laccase-producing basidiomycetes proved successful in increasing of enzyme production.
\end{abstract}

A. Antecka ( $₫)$ · M. Blatkiewicz · M. Bizukojć ·

S. Ledakowicz

Department of Bioprocess Engineering, Lodz University of Technology, ul. Wolczanska 213, 90-924 Lodz, Poland e-mail: anna.antecka@p.lodz.pl
Keywords Basidiomycetes · Fungal morphology · Laccase $\cdot$ Microparticle-enhanced cultivation

\section{Introduction}

Laccase (EC 1.10.3.2) is a copper-containing oxidase that catalyze reduction of $\mathrm{O}_{2}$ to $\mathrm{H}_{2} \mathrm{O}$ using the variety of phenolic substrates as hydrogen donors. Laccase can convert o- and p-diphenols, aminophenols, polyphenols, polyamines and recalcitrant non-phenolic lignin compounds (Mayer and Staples 2002). Therefore, this enzyme can be applied for a number of biotechnological problems related to the degradation or chemical modification of structurally diverse compounds, being either xenobiotics or naturally occurring aromatic compounds (Couto and Herrera 2006; Imran et al. 2012).

However, the cultivation of fungal, especially basidiomycetes, cultures is a more complicated task than that of bacterial ones as the individual fungal strain can demonstrate a wide range of morphologies dependent on the age of mycelium, cultivation media composition, $\mathrm{pH}$ shifting and mechanical stress (Krull et al. 2013). What is more, fungal morphology, namely diameter of pellets and their structure, affects the titers of produced metabolites to the high extent (Bizukojc and Ledakowicz 2010) and changing fungal morphology with the use of morphological engineering techniques, like microparticle-enhanced cultivation 
(MPEC) often leads to improving the production of metabolites and enzymes (Krull et al. 2013).

In the pioneering study the use of such inorganic microparticles as $\mathrm{Al}_{2} \mathrm{O}_{3}$ or talc added to the fungal cultures, namely MPEC technique, was introduced to influence on Caldariomyces fumago morphology and enhance chloroperoxidase production (Kaup et al. 2008). Other authors also observed that intentional supplementation of microparticles to fungal cultures generally stimulated growth of these organisms as well as biosynthesis of selected enzymes. MPEC applied for Aspergillus niger led to the formation of freely dispersed mycelium, which occurred to be favorable for high productivity of glucoamylase (Driouch et al. 2010). Talc microparticles decreased pellet diameter in Aspergillus terreus and improved lovastatin production (Gonciarz and Bizukojc 2014).

The only literature data concerning the effect of microparticles on laccase production come from Tišma et al. (2012). They explored its production by Trametes versicolor on industrial waste and found that microparticles of $\mathrm{CaCO}_{3}$ unintentionally present in the waste substrate changed fungal morphology and enhanced laccase activity. Upon these findings we attempted to apply MPEC for the first time for basidiomycetous white rot fungi Cerrena unicolor and Pleurotus sapidus in order to intensify laccase biosynthesis.

\section{Methods}

Cerrena unicolor (Bull. ex Fr.) Murr. strain 137 used in this study was obtained from the culture collection of Department of Biochemistry, Maria CurieSkłodowska University, Lublin, Poland. Stock cultures were maintained on malt extract agar (MEA) slants at $4{ }^{\circ} \mathrm{C}$.

Pleurotus sapidus (DSM 8266) strain was obtained from DSMZ and maintained on malt extract peptone agar.

The experiments were run in $500 \mathrm{ml}$ shake flasks containing $200 \mathrm{ml}$ of Lindeberg-Holm liquid medium as described previously (Janusz et al. 2007) for $C$. unicolor and modified Zorn medium (Zorn et al. 2003) for $P$. sapidus. For $P$. sapidus the additional experiments were required to find the optimal $\mathrm{Cu}^{2+}$ concentration in the medium. Liquid media were sterilized at $121{ }^{\circ} \mathrm{C}$ and 1.6 bar for $15 \mathrm{~min}$.
For the cultivations with microparticles the following concentrations of $\mathrm{Al}_{2} \mathrm{O}_{3}$ were selected: 5, 10, 15,20 and $30 \mathrm{~g} \mathrm{Al}_{2} \mathrm{O}_{3} \mathrm{I}^{-1}$. The use of $\mathrm{Al}_{2} \mathrm{O}_{3}$ was justified by the fact that out of many types of microparticles used in MPEC they belong to the most inactive ones (Etschmann et al. 2015). The portions of microparticles were prepared separately and sterilized in the same conditions as the culture medium. In all experiments the inoculation was made with a $5 \mathrm{ml}$ of homogenized fungal mycelium from the overgrown agar plates. Next, $\mathrm{Al}_{2} \mathrm{O}_{3}$ was added, excluding the flasks for the control run. All flasks were incubated on a rotary shaker (Sartorius, Germany) at $28{ }^{\circ} \mathrm{C}$ and constant rotary speed of $110 \mathrm{rpm}$ for 14 days. The liquid medium was separated from biomass by filtration on paper filters (Filtrak, Germany). The supernatant was used for further analyses.

Laccase activity was determined in the culture liquid by measuring the oxidation of $0.5 \mathrm{mM}$ syringaldazine dissolved in ethanol buffered in $0.1 \mathrm{M}$ citrate-buffer $\left(\mathrm{pH}\right.$ 5.6, $\varepsilon_{525}=65 \mathrm{mM}^{-1}$ $\mathrm{cm}^{-1}$ ). All spectrophotometric measurements were carried out using a UV-300 spectrophotometer (Unicam, Cambridge, UK). Enzyme activities were expressed in $\mathrm{U}^{-1}$, where units (U) were defined as $1 \mu \mathrm{mol}$ of product formed per one minute. Biomass concentration was assayed as dry weight of the fungal mycelium. All chemicals were obtained from SigmaAldrich (Steinheim, Germany) and Merck (Darmstadt, Germany). $\mathrm{Al}_{2} \mathrm{O}_{3}$ microparticles of mean diameter equal to $10 \mu \mathrm{m}$ were purchased from Sigma-Aldrich.

\section{Results and discussion}

The purpose of the first series of the experiments was to examine the influence of $\mathrm{Al}_{2} \mathrm{O}_{3}$ microparticles on laccase production. For $C$. unicolor laccase activity was detected on 6 day of the cultivation (Fig. 1a) at all tested concentrations of $\mathrm{Al}_{2} \mathrm{O}_{3}$. The positive influence of microparticles on laccase activity was observed starting with $5 \mathrm{~g} \mathrm{Al}_{2} \mathrm{O}_{3} \mathrm{l}^{-1}$ and next laccase activity increased with the increasing concentration of $\mathrm{Al}_{2} \mathrm{O}_{3}$. On 9 day of the process much higher activities up to $2233 \mathrm{U}^{-1}$ were observed. $\mathrm{At}^{\mathrm{Al}_{2} \mathrm{O}_{3}}$ concentrations equal to 5 and $10 \mathrm{~g} \mathrm{Al}_{2} \mathrm{O}_{3} 1^{-1} 2.5$ - and 1.7-fold increases of laccase activity were 


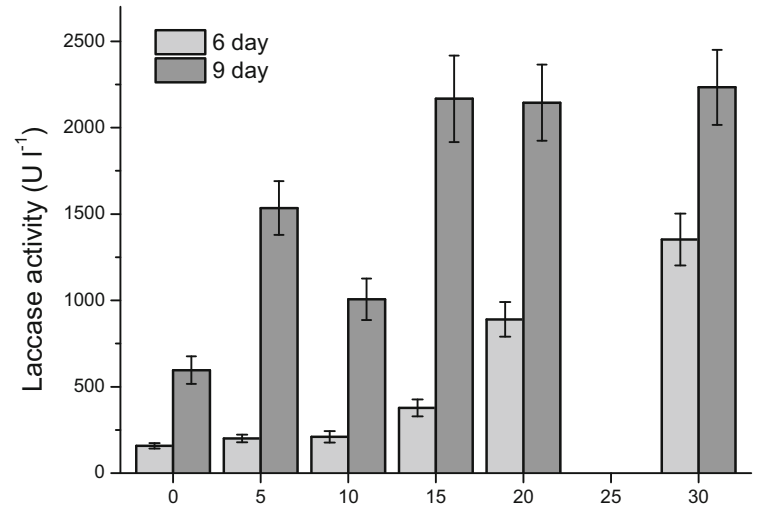

A

$\mathrm{Al}_{2} \mathrm{O}_{3}$ concentration $\left(\mathrm{g} \mathrm{I}^{-1}\right)$

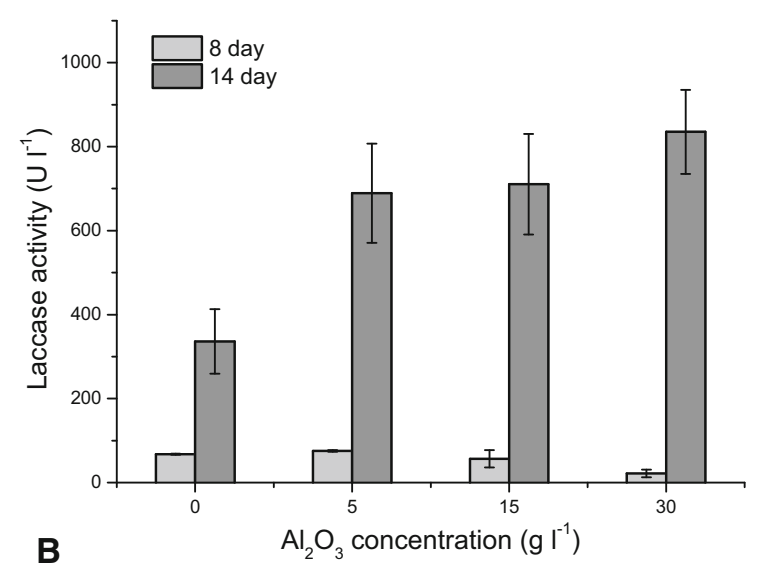

Fig. 1 Influence of $\mathrm{Al}_{2} \mathrm{O}_{3}$ microparticles concentration on laccase activity for $\mathbf{a} C$. unicolor and $\mathbf{b} P$. sapidus; the presented points represent the averaged values from three experiments and error bars are standard deviation

respectively found, while the runs with the addition of 15,20 and $30 \mathrm{~g} \mathrm{Al}_{2} \mathrm{O}_{3} \mathrm{1}^{-1}$ resulted in a 3.5 -fold increase of laccase activity. The similar effect of the increase of laccase activity was described for Trametes versicolor growing on the medium containing $\mathrm{CaCO}_{3}$ microparticles (Tišma et al. 2012), in which the several-fold increase of laccase activity was observed. Furthermore, it was found in the current study that increasing microparticle concentrations above $15 \mathrm{~g} \mathrm{Al}_{2} \mathrm{O}_{3} 1^{-1}$ did not cause any significant change in laccase production by $C$. unicolor. It was similar to the previous findings for Caldariomyces fumago culture, in which talc or $\mathrm{Al}_{2} \mathrm{O}_{3}$ concentrations between 10 and $15 \mathrm{~g}^{-1}$ enhanced biomass formation and chloroperoxidase activity but further increase of microparticles concentration had no effect on the culture (Kaup et al. 2008).
A different situation was observed for $P$. sapidus (Fig. 1b) as laccase activity in all runs was not detectable until 8 day of cultivation. There was a 2-days delay compared to $C$. unicolor. But more interesting was the fact that the change of $\mathrm{Al}_{2} \mathrm{O}_{3}$ microparticles concentration did not influence on laccase activity to such an extent as it did for $C$. unicolor. On 14 day of the cultivation laccase activity for $P$. sapidus reached the highest value of $835 \mathrm{U}^{-1}$ and regardless of $\mathrm{Al}_{2} \mathrm{O}_{3}$ microparticles concentration all laccase activities found were more or less twice higher than those in the control run.

Unlike $P$. sapidus, C. unicolor, with regard to microparticles concentration, behaved similarly to the filamentous fungi A. niger, whose fructofuranosidase activity changed several-fold with $\mathrm{Al}_{2} \mathrm{O}_{3}$ concentration between 5 and $30 \mathrm{~g} \mathrm{Al}_{2} \mathrm{O}_{3} \mathrm{l}^{-1}$ (Driouch et al. 2011).

The conducted experiments showed that the mycelial growth of $C$. unicolor in the cultures containing $\mathrm{Al}_{2} \mathrm{O}_{3}$ microparticles, especially at their concentrations exceeding $15 \mathrm{~g} \mathrm{Al}_{2} \mathrm{O}_{3} \mathrm{l}^{-1}$, was faster. What is more, at $\mathrm{Al}_{2} \mathrm{O}_{3}$ concentrations below $15 \mathrm{~g}$ $\mathrm{Al}_{2} \mathrm{O}_{3} \mathrm{l}^{-1}$ all microparticles were ultimately built into the mycelial agglomerates (pellets). But at 20 and $30 \mathrm{~g}$ $\mathrm{Al}_{2} \mathrm{O}_{3} \mathrm{l}^{-1}$ there were microparticles freely suspended in the liquid medium.

In the second series of experiments, $\mathrm{Al}_{2} \mathrm{O}_{3}$ concentrations of 15 and $30 \mathrm{~g} \mathrm{Al}_{2} \mathrm{O}_{3} \mathrm{l}^{-1}$ were selected for both studied fungal species. Microparticles concentration of $15 \mathrm{~g} \mathrm{Al}_{2} \mathrm{O}_{3} \mathrm{l}^{-1}$ was believed to be optimal due to the highest laccase activity, visible changes of fungal morphology and the fact that the microparticles were fully built into the fungal agglomerates. Microparticles concentration of $30 \mathrm{~g} \mathrm{Al}_{2} \mathrm{O}_{3} \mathrm{l}^{-1}$ was chosen because of the high laccase activity on 6 day of the experiment.

In Fig. 2 it is seen that regardless of $\mathrm{Al}_{2} \mathrm{O}_{3}$ concentration there was no enzymatic activity in the broth before 5 and 6 day of the experiment, respectively for $C$. unicolor (Fig. 2a) and $P$. sapidus (Fig. 2b). For C. unicolor at $30 \mathrm{~g} \mathrm{Al}_{2} \mathrm{O}_{3} \mathrm{l}^{-1}$ the increase in laccase activity was observed on 7 day and was faster than those for the other two experiments. Laccase activity reached then its maximum of $2387 \mathrm{U}^{-1}$ on 8 day and later began to decrease. For $15 \mathrm{~g} \mathrm{Al}_{2} \mathrm{O}_{3} \mathrm{l}^{-1}$ a similar increase of laccase activity was observed between 7 and 8 day of the experiment

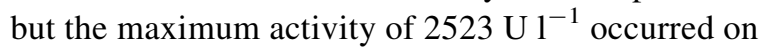



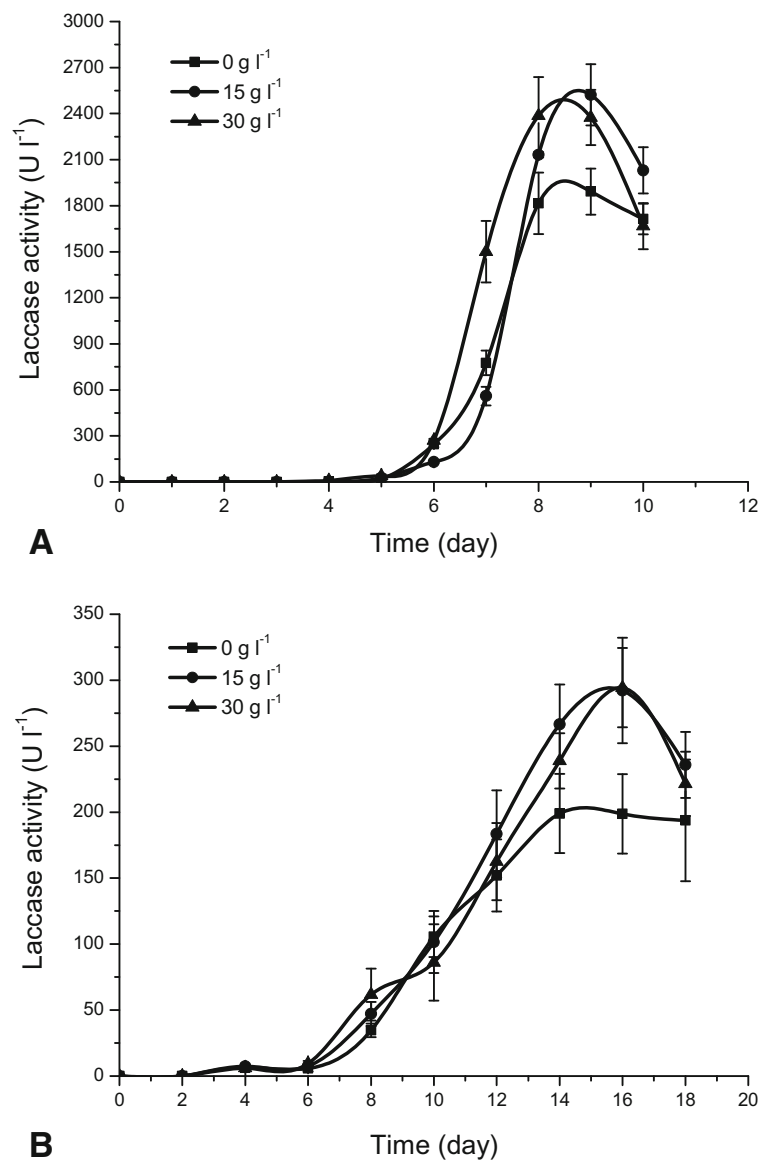

Fig. 2 Time changes of laccase activity at various $\mathrm{Al}_{2} \mathrm{O}_{3}$ concentration added to the culture of $\mathbf{a} C$. unicolor and $\mathbf{b} P$. sapidus; the presented points represent the averaged values from three experiments and error bars are standard deviation

9 day and it was the highest activity out of all experiments.

For $P$. sapidus the highest laccase activity of 294 $\mathrm{U}^{-1}$ was detected on 16 day, i.e. 7 days later than it was for $C$. unicolor. Two tested $\mathrm{Al}_{2} \mathrm{O}_{3}$ concentrations resulted in the similar laccase activities in $P$. sapidus.

All these changes in laccase activity for both studied species were attributed to the changes in the size and shape of agglomerates (pellets), namely fungal morphology. The images of growing biomass are presented in Fig. 3 for C. unicolor and in Fig. 4 for P. sapidus. For both fungal strains the change in the size and shape as well as in the structure of the pellets were observed.

For C. unicolor when no microparticles were added (Fig. 3a) smooth, sometimes slightly fluffy pellets with some dispersed hyphae were observed. Diameters of pellets ranged from 2 to $6 \mathrm{~mm}$ and were significantly higher than those of pellets coming from the media containing $\mathrm{Al}_{2} \mathrm{O}_{3}$ microparticles. In the case of $15 \mathrm{~g} \mathrm{Al}_{2} \mathrm{O}_{3} \mathrm{l}^{-1}$ added (Fig. 3b) hairy and starshaped pellets were formed. Their diameters were lower than those in the run without microparticles and ranged from 1 to $4 \mathrm{~mm}$. Biomass from the cultures, to which $30 \mathrm{~g} \mathrm{Al}_{2} \mathrm{O}_{3} \mathrm{l}^{-1}$ were added (Fig. 3c), grew partly in the form of pellets but also much dispersed hyphae were observed. Also these pellets had a characteristic star-shaped form and looser structure. The size of the pellets was between 1 and $3 \mathrm{~mm}$. The similar decrease in the pellet size and formation of freely dispersed mycelium was also observed by Driouch et al. (2011) for A. niger morphologically engineered with the use of either talc or $\mathrm{Al}_{2} \mathrm{O}_{3}$ microparticles.

For P. sapidus (Fig. 4a-c) the addition of microparticles led to the formation of smaller but more compact pellets. However, no significant difference in pellet morphology at various $\mathrm{Al}_{2} \mathrm{O}_{3}$ concentrations was seen. In many cases there was a visible core in the centre of the pellet, in which the microparticles were incorporated (Fig. 4b, c). This type of pellets was previously called core-shell pellets by Driouch et al. (2012) and these authors obtained them with the use of titanate microparticles towards fructofuranosidase and glucoamylase producer A. niger. Opposite to C. unicolor cultivations there were no remaining microparticles in the medium even at $30 \mathrm{~g} \mathrm{Al}_{2} \mathrm{O}_{3} \mathrm{I}^{-1}$. It meant that all added microparticles were built into $P$. sapidus biomass.

The formation of smaller pellets exerted by the addition of microparticles is the phenomenon often described in literature for Aspergilli (Walisko et al. 2012). It is actually the aim of microparticleenhanced cultivation to produce smaller and less dense pellets by interfering with agglomeration of fungal spores. Here, more interesting is the fact that the microparticles acted directly on the agglomeration of free hyphae and the change in structure of the fungal morphology was different for two basidiomycetes strains studied.

Summing up, as the increase of laccase activity occurred to be significant and the microparticles used are easily available and inexpensive, MPEC is a simple and effective strategy to intensify biotechnological laccase production by basidiomycetes. 


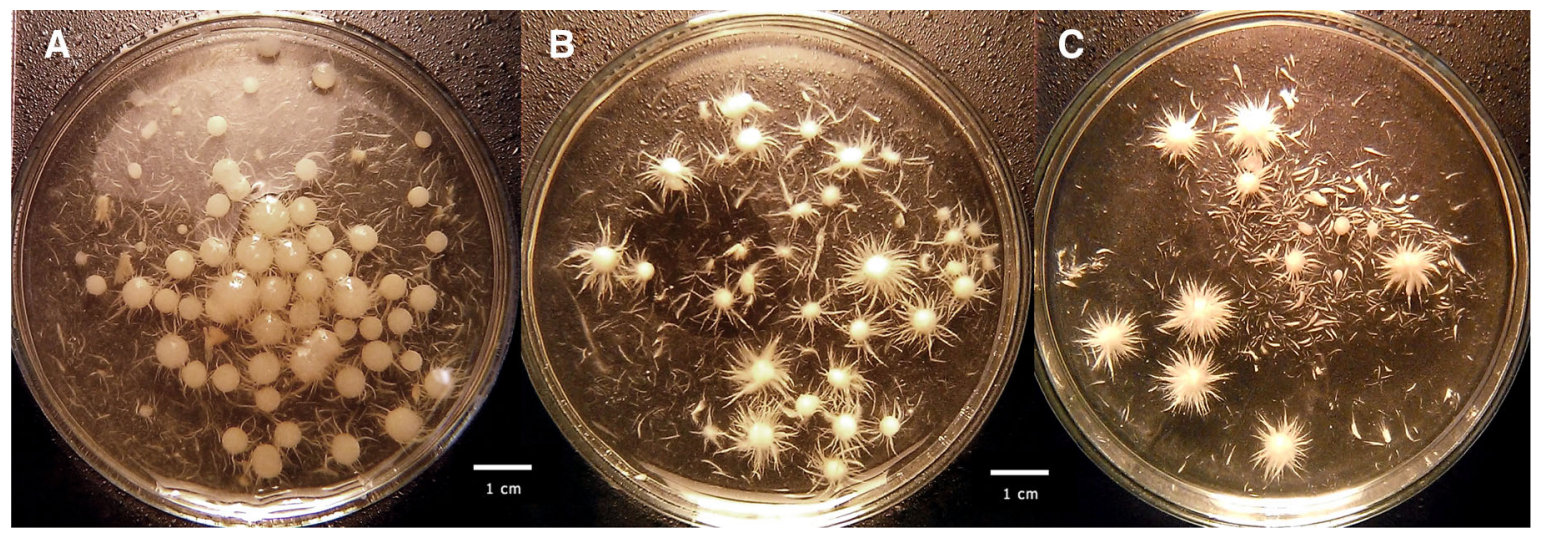

Fig. 3 Influence of $\mathrm{Al}_{2} \mathrm{O}_{3}$ microparticles added to the culture medium on $C$. unicolor morphology: a control run without microparticles, b $15 \mathrm{~g} \mathrm{Al}_{2} \mathrm{O}_{3} \mathrm{l}^{-1}$ and $\mathbf{c} 30 \mathrm{~g} \mathrm{Al}_{2} \mathrm{O}_{3} \mathrm{l}^{-1}$; scale-bar size $1 \mathrm{~cm}$

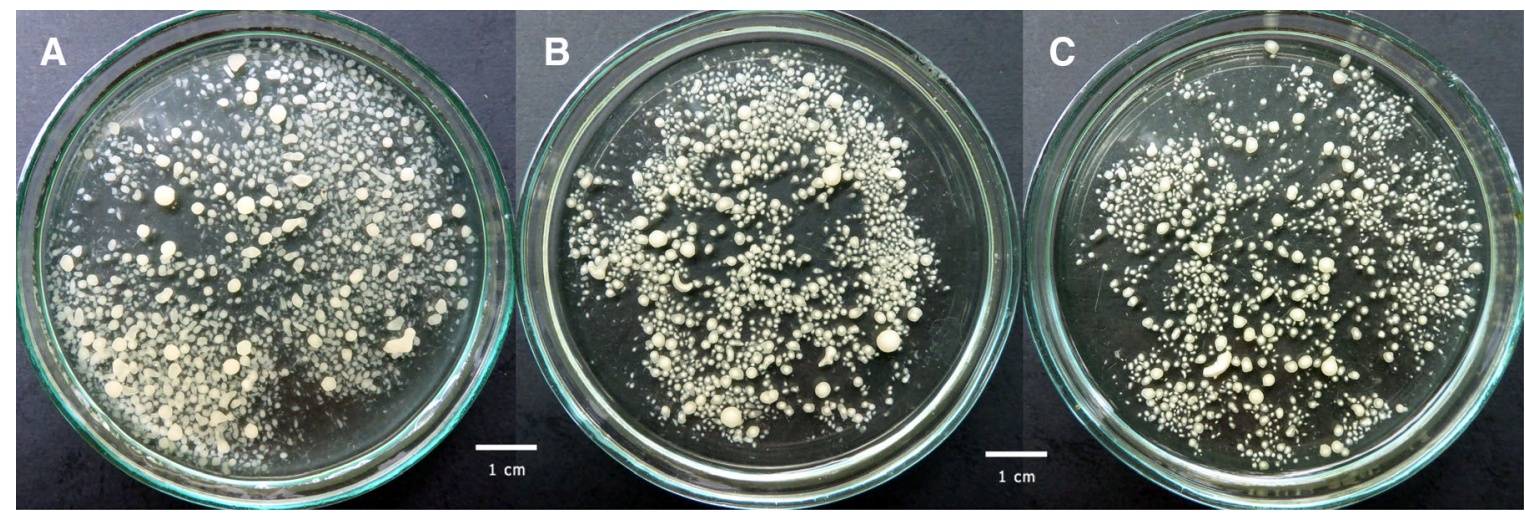

Fig. 4 Influence of $\mathrm{Al}_{2} \mathrm{O}_{3}$ microparticles added to the culture medium on P. sapidus morphology: a control run without microparticles, b $15 \mathrm{~g} \mathrm{Al}_{2} \mathrm{O}_{3} \mathrm{l}^{-1}$ and c $30 \mathrm{~g} \mathrm{Al}_{2} \mathrm{O}_{3} \mathrm{l}^{-1}$; scale-bar size $1 \mathrm{~cm}$

\section{Conclusions}

(1) The applied $\mathrm{Al}_{2} \mathrm{O}_{3}$ microparticles in the culture of two basidiomycetes species at concentration $15 \mathrm{~g} \mathrm{Al}_{2} \mathrm{O}_{3} \mathrm{1}^{-1}$ cause the increase of laccase activities, respectively 3.5 -fold for $C$. unicolor and 2-fold for $P$. sapidus compared to the control run without microparticles.

(2) Addition of $\mathrm{Al}_{2} \mathrm{O}_{3}$ microparticles decreases pellet size for both studied species but the changes in the structure of agglomerates are different for each of them. C. unicolor pellets get more hairy up to the transformation into dispersed morphology. For P. sapidus pellets are more compact and have the characteristic core with the incorporated microparticles.
Acknowledgments The work was supported by the National Science Center (Republic of Poland) within the Project Number: UMO-2013/11/B/ST8/00337.

Open Access This article is distributed under the terms of the Creative Commons Attribution 4.0 International License (http:// creativecommons.org/licenses/by/4.0/), which permits unrestricted use, distribution, and reproduction in any medium, provided you give appropriate credit to the original author(s) and the source, provide a link to the Creative Commons license, and indicate if changes were made.

\section{References}

Bizukojc M, Ledakowicz S (2010) The morphological and physiological evolution of Aspergillus terreus mycelium in the submerged culture and its relation to the formation of 
secondary metabolites. World J Microbiol Biotechnol 26:41-54

Couto SR, Herrera JLT (2006) Industrial and biotechnological applications of laccases: a review. Biotechnol Adv 24:500-513

Driouch H, Sommer B, Wittmann C (2010) Morphology engineering of Aspergillus niger for improved enzyme production. Biotechnol Bioeng 105:1058-1068

Driouch H, Roth A, Dersch P, Wittmann C (2011) Filamentous fungi in good shape: microparticles for tailor-made fungal morphology and enhanced enzyme production. Bioeng Bugs 2:100-104

Driouch H, Hänsch R, Wucherpfennig T, Krull R, Wittmann C (2012) Improved enzyme production by bio-pellets of Aspergillus niger: targeted morphology engineering using titanate microparticles. Biotechnol Bioeng 109:462-471

Etschmann MMW, Huth I, Walisko R, Schuster J, Krull R, Holmann D, Wittmann C, Schrader J (2015) Improving 2-phenylethanol and 6-pentyl-a-pyrone production with fungi by microparticle-enhanced cultivation. Yeast 32:145-157

Gonciarz J, Bizukojc M (2014) Adding talc microparticles to Aspergillus terreus ATCC 20542 preculture decreases fungal pellet size and improves lovastatin production. Eng Life Sci 14:190-200

Imran M, Asad M, Hadri S, Mehmood S (2012) Production and industrial applications of laccase enzyme. J Cell Mol Biol 10:1-11
Janusz G, Rogalski J, Szczodrak J (2007) Increased production of laccase by Cerrena unicolor in submerged liquid cultures. World J Microbiol Biotechnol 23:1459-1464

Kaup B, Ehrich K, Pescheck M, Schrader J (2008) Microparticle-enhanced cultivation of filamentous microorganisms: increased chloroperoxidase formation by Caldariomyces fumago as an example. Biotechnol Bioeng 99:491-498

Krull R, Wucherpfennig T, Eslahpazir Esfandabadi M, Walisko R, Melzer G, Hempel D, Kampen I, Kwade A, Wittmann C (2013) Characterization and control of fungal morphology for improved production performance in biotechnology. J Biotechnol 163:112-123

Mayer AM, Staples RC (2002) Laccase: new functions for an old enzyme. Phytochemistry 60:551-565

Tišma M, Žnidaršič-Plazl P, Vasić-Rački D, Zelić B (2012) Optimization of laccase production by Trametes versicolor cultivated on industrial waste. Appl Biochem Biotechnol 166:36-46

Walisko R, Krull R, Schrader J, Wittmann Ch (2012) Microparticle based morphology engineering of filamentous microorganisms for industrial bio-production. Biotechnol Lett 34:1975-1982

Zorn H, Breithaupt D, Takenberg M, Schwack W, Berger R (2003) Enzymatic hydrolysis of carotenoid esters of marigold flowers (Tagetes erecta L.) and red paprika (Capsicum annum L.) by commercial lipases and Pleurotus sapidus extracellular lipase. Enz Microb Technol $32: 623-628$ 